\title{
Perceptions of EFL Learners in the Implementation of Blended Learning Post-natural Disaster at a University in Indonesia
}

\author{
Grace N. Manurung \\ Department of English Education, Postgraduate Program, Tadulako University, Palu, Indonesia \\ Konder Manurung \\ Department of English Education, Faculty of Teacher Training and Education, Tadulako University, Palu, Indonesia \\ Sudarkam R. Mertosono \\ Department of English Education, Faculty of Teacher Training and Education, Tadulako University, Palu, Indonesia \\ Abdul Kamaruddin \\ Department of English Education, Faculty of Teacher Training and Education, Tadulako University, Palu, Indonesia
}

\begin{abstract}
This study aims to investigate the perceptions and obstacles faced by EFL learners in the implementation of blended learning in an abnormal learning system. A group of undergraduate EFL learners, consisting of 48, who has completed a Grammar Class, participated in the study. The 48 learners formed three different learner category levels; High, Moderate, and Low. The learners of the three different category levels filled in a semi-structured open-ended questionnaire and responded semi-structured interviews. The low category learners perceive that learning grammar through blended learning is meaningful but need more experiences in the utilization of online learning mode, and in-availability of the supporting tools; The moderate category learners perceive blended learning to provide them more study times and make them get used to the internet or online-based learning; and the high category learners perceive the implementation of blended learning as helpful, easier, flexible, and fun. Although the learners of the three different categories level face the same problems on the implementation of blended learning, namely poor internet connectivity at home and campus, unclear online instruction, and delay to respond questions on the online learning mode, the learners of the low category level, on the other hand, experience problems applying online learning mode. We discuss the practical implications of the research results for the successful implementation of blended learning in the future, especially for low proficiency learners and in situations of abnormal learning systems.
\end{abstract}

Index Terms - perceptions, blended learning, teaching grammar, post-natural disaster, abnormal learning systems

\section{INTRODUCTION}

The implementation of Blended Learning provides learners with comfort on the use of online learning and the conventional learning method (Dziuban et al., 2004). The facilitation of conducting a combination of face to face and online learning in the blended learning leads the teaching and learning process into a more flexible and interactive ways due to the involvement of Information and Communication Technology (ICT). Along with the progress of ICT, language teaching and learning is getting more joyful, flexible, and interactive (Bonk \& Graham, 2006; Campbell et al., 2008). More importantly, blended learning systematically combine times and modes of learning, integrate the best aspects of face-to-face and online interactions, utilization of appropriate ICTs (The University of Western Sydney, 2013) and that blended learning is not only beneficial for learners (Abdelhak, 2015) but also the teaching staff (The University of Western Sydney, 2013). Besides, through blended learning, the learners can learn at anytime and anywhere (Department of Education and Early Childhood Development Victoria, 2012).

The blended learning, where ICT advancement is involved, contributes significantly to the language learning and teaching process. Some language researchers and practitioners reveal the effectiveness of the blended learning in the language teaching and learning process (Driscoll, 2002; Dziuban et al., 2004; Neumeier, 2005; Banados, 2006; Yarbro et al., 2016; Selwyn, 2016). The involvement of ICT in language teaching and learning has long been experienced in the history of language teaching in various modes from the naissance of the independent or autonomous learning in the form of Self-Access Centre (SAC) learning mode (see for examples, Sheerin, 1989; Pierce, 1995; Manurung, 2005), the graphical web browser software, Words Wide Web (or Web) (Lin, 1997), Computer Assisted Language Learning (CALL) (Campbell et al., 2008), to the present involvement of ICT in Hybrid Learning in language teaching and learning which is better known as Blended Learning that characterizes the Industrial Revolution 4.0 Era. 
Most language researchers and practitioners reveal that the implementation of blended learning in language teaching is beneficial (Lin, 1997; Ayres, 2002; Ellis, 2003; Byrne, 2007; Tuson, 2015). Lin (1997) revealed that teaching of grammar using ICT was helpful to enhance individualized learning, Ayres (2002) reported the positive effect of the implementation of blended learning on Grammar and Spelling, Tuson (2012) reported the advantages of the implementation of blended learning in teaching Vocabulary, and Byrne (2007) reported the effectiveness of the implementation of blended learning in teaching writing. However, some language researchers and practitioners report that not all language skills and components get equally improved after implementing blended learning (Bueno-Alastuey and López-Pérez, 2014; Selwyn, 2016). Bueno-Alastuey and López-Pérez (2014) reveal that the "learners with the increased use of technology improve more in productive skills and the learners who had used ICT less in their course improve in grammar and vocabulary" (p. 1). Also, Selwyn (2016) reveals "the importance of guidance and training to satisfy the needs of learners in the use of ICT with language learning" (p. 1). However, it is revealed that the conventional language learning is more effective when it is combined with ICT (Al-Jarf, 2005; Yang and Chen, 2007; Manurung, 2015). More importantly, blended learning copes with limited time available in the conduct of face to face learning (Banados, 2006; Sahin-Kizil, 2014).

Due to the great findings of the effectiveness of blended learning from the language researchers and practitioners, it is necessary to investigate what the perceptions of the learners are in this modern teaching mode. Basioudis et al., (2012) argue that the perception of the learners is influential in the implementation of blended learning to highlight their active participation. This is in line with Ginns \& Ellis (2007) arguing the importance of investigating the implementation of online learning to find out how it supports the teaching and learning process. More importantly, Basioudis et al., (2012) argue the importance of knowing learners' perceptions not only on the teaching method but also on instructional materials and management. They note that learners' perception of blended learning, management system, and the instructional materials influence the learning engagement of the learners.

Few studies have been conducted in EFL learning in Indonesia regarding the perception of the implementation of blended learning (Pardede, 2011; Nazara \& Wardiningsih, 2016; Maudra, 2018). Pardede (2011) reveals that the learners perceive internet-based technology is beneficial as supplementary materials. Nazara \& Wardiningsih (2016) investigate both the perceptions of learners on face-to-face learning and the Blended Learning modes and reveal that the perception of the learners is moderate on the face-to-face learning and positive on the Blended Learning. On the other hand, Maudra (2018) reported difficulties experienced by pre-service EFL teachers on the internet connection when they did their teaching practice at rural schools. Some other researchers worldwide, interestingly, have investigated the perceptions of learners on motivation and satisfaction in the implementation of blended learning as compared to the classroom teaching mode (Allen et al., 2002; Ginns \& Ellis, 2007; Driscoll, 2002; Pollard, 2015). Driscoll (2002) reveal that the learners perceive equal satisfaction on the implementation of blended learning and the classroom teaching model. However, Ginns \& Ellis (2007) and Pollard (2015) report that the learner perceives significant difference satisfaction between classroom teaching and the online learning mode. However, Allen at el., (2002) reveal that the learners perceive there is a difference in the learners' satisfaction regarding the face to face teaching and the one line learning mode but the difference is not significant.

Some researchers have also investigated the perceptions of the learners in the implementation of blended learning in the teaching of the language components and the language skills (Lin, 1997; Tuson, 2015; Byrne, 2007; Lee \& Chong; 2007; Flórez et al., 2012). Some of the researchers reveal a positive perception of the learners in the implementation of blended learning in teaching language components (Lin, 1997; Lee \& Chong, 2007; Tuson, 2015). The learners also perceive the implementation of blended learning in teaching language skills is positive (Byrne, 2007; Lee \& Chong; 2007; Flórez et al., 2012). The differences in the perceptions on the implementation of blended learning are interesting and therefore the present study enriches the perception by investigating from the perspective of an abnormal learning system and of different category levels of learners.

\section{ThE STUdY}

In the present study, we investigated the perceptions of undergraduate EFL learners and the obstacles they faced during the implementation of blended learning in an abnormal learning system post-natural disaster at the Department of English Education, Faculty of Teacher Training and Education, Tadulako University Palu, Indonesia. The department provided 50 minutes per credit unit on a course in a normal learning system and therefore there would be 100 minutes for a course of two credit units, and 150 minutes for the courses of three credit units. However, due to the limited amount of classrooms available at the department post-natural disaster; earthquake, tsunami, and liquefaction, after the damage of around $70 \%$ classrooms at the university, the teaching for all classes lasted for fifty minutes regardless the credit unit weighed to the courses programmed. The university management chose blended learning mode to cope with the limited time to conduct the face to face teaching in the classroom. This choice is in line with the implementation of Indonesian National Qualification Framework (IQF) oriented curriculum at Higher Education Institutions (HEIs) in Indonesia (Manurung, 2018). To investigate the perceptions of the learners and the obstacles they faced during the implementation of blended learning in the abnormal learning system at the department, we posed two questions; first, what is the perception of the EFL learners on the implementation of blended learning? Second, what are the obstacles of the learners in the implementation of blended learning? Whereas most of the previous research on the perception of the 
learners on the implementation of blended learning emphasizes general perception, the present study investigates the perceptions of learners from three different levels of categories namely, high, moderate, and low. The achievement of the learners at the end of the courses placed the learners into those levels of categories.

\section{THE METHOD OF RESEARCH}

The present study applied descriptive qualitative. Seliger and Shohamy (1990) argue "the ultimate goal of qualitative research is to discover phenomena" (p. 120), and "qualitative research appears to be more appropriate for describing the social context of a second language" (p. 121). Besides, Singh (2006) emphasize that "the main objectives of descriptive research are to identify present conditions and point to present needs, to study the immediate status of a phenomenon, facts findings, to examine the relationship of traits and characteristics" (p.105). This is in line with Lambert (2012) who emphasized that Descriptive Qualitative Research is a comprehensive summarization of specific events experienced by individuals or groups of individuals, and Creswell (2014) argues the importance of experiences from participants. These point of views of descriptive qualitative research highlighted that the method intends to explain and describes phenomena which are experienced in a particular social situation. Concerning the previously identified research problems of this research, learners' perception and obstacles in learning on the implementation of blended learning, as experienced by EFL learners, the application of Descriptive Qualitative Research meets the objectives of the research.

\section{A. The Participants}

Purposive sampling techniques satisfy the assignment of the participants in the present study. Maxwell (1997) defines that "purposive sampling is a technique of sampling in which particular settings, persons, or events are deliberately selected for the important information they can provide that cannot be gotten as well from other choices" (p.87). This is in line with Sugiyono (2012) argued that qualitative research employed a theoretic sample that is chosen purposively. The sample was chosen for a particular reason and purpose. Besides, Creswell (2012) argued that the idea behind qualitative research is to purposefully select participants or sites (or documents or visual material) that best help the researcher understand the problem and the research question. Based on those viewpoints, therefore, we chose the participants of this research purposively, those who have participated in the teaching of Grammar by applying blended learning, which was class D of 2018 academic year totaling to 48 learners. The 48 learners agreed to participate in the study.

\section{B. The Data Collection}

We used three methods to collect data in the present study, namely, documentation, open-ended semi-structured questionnaire, and semi-structured interview. Seliger and Shohamy (1990) and Creswell (2014) highlighted that data in qualitative research are collected by using more than one procedure simultaneously. This is in line with Sugiyono (2012) who argued that Qualitative researchers typically gather multiple forms of data, such as interviews, observations, documents, and audiovisual information rather than rely on a single data source. Then the researchers review all of the data, make sense of it, and organize it into categories or themes that cut across all of the data sources. Seliger and Shohamy (1990) emphasized that the use of a variety of methods of data collection also facilitates validation and triangulation, the confirm-ability of the findings. Based on the above suggested qualitative data collection procedures, we collected data through documentation, questionnaire, and interview. We investigated the documentations on the grade of the learners after the implementation of blended learning (Manurung et al., (2019), and analyzed them descriptively to classify the learners into category levels. We also investigated documentation regarding the classification or the category of the grade used in the Department of English Education. We found the grade classification on the course syllabus and adapted it to classify the grade of the learners into low, moderate, and high. The three different levels of learners filled in the open-ended semi-structured questionnaire and responded to the semistructured interview. We developed the questionnaire items around the implementation of the Blended Learning and the semi-structured interview around the difficulties or obstacles faced during the implementation of blended learning. This is in line with Seliger and Shohamy (1990) who argued that open questionnaire is one of the typical devices and procedures in qualitative research, and the semi-structured interview consists of specific and defined questions determine beforehand ..." (p.167).

\section{The Data Analysis}

We analyzed the data descriptively and qualitatively. First, we analyzed the data from the documentation descriptively to categorize the levels of the learners. Second, we analyzed the data from the open-ended semi-structured questionnaire and the semi-structured interview qualitatively (Neuendorf, 2002; Creswell, 2014). Neuendorf (2002) argues that units of meaning for the qualitative analysis were phrases, sentences, or more than one sentence indicating one category or sub-category item. Also, Creswell (2014) proposed the steps to analyze the data from transcribing the data, getting the general sense of the information, organizing the data, describing the data, to interpreting the data. Therefore, we analyzed the data based on the previously proposed questions; what is the perception of the EFL learners on the implementation of blended learning, and what are the obstacles faced by the EFL learners in the teaching and learning process in the implementation of blended learning?" For the data analysis, we did not mention the names of those 48 participants, we coded every participant instead from Q1 to Q48. 


\section{RESULTS}

\section{A. Achievement Level Category}

The results of the descriptive analysis on the documentation regarding the achievement grade of the learners after the implementation of blended learning, as described in Table 1 (Manurung et al., 2019), reveal that there are 25 out of 48 , or $52 \%$, learners are categorized as a high level where the grade is between 81 and 100, 14 out of 48 or $29 \%$, are moderate level where the grade between 71 and 80 , and 9 out of 48 or $19 \%$, are low level where the grade is $\leq 70$.

TABLE 1

THE DESCRIPTION OF THE STUDENTS' ACHIEVEMENT

\begin{tabular}{|c|c|c|c|c|c|}
\hline \multicolumn{2}{|c|}{ Score } & \multirow{2}{*}{ No of Students } & \multirow{2}{*}{ Classification } & \multirow{2}{*}{ Total } & \multirow{2}{*}{ Percentage } \\
\hline Figure & Letter & & & & \\
\hline $86-100$ & $\mathrm{~A}$ & 20 & \multirow{2}{*}{ High } & \multirow{2}{*}{25} & \multirow{2}{*}{52} \\
\hline $81-85$ & A- & 5 & & & \\
\hline $76-80$ & $\mathrm{~B}+$ & 8 & \multirow{2}{*}{ Moderate } & \multirow{2}{*}{14} & \multirow{2}{*}{19} \\
\hline $71-75$ & $\mathrm{~B}$ & 6 & & & \\
\hline $66-70$ & B- & 6 & \multirow{2}{*}{ Low } & \multirow{2}{*}{9} & \multirow{2}{*}{19} \\
\hline 61-69 & $\mathrm{C}$ & 3 & & & \\
\hline \multicolumn{2}{|c|}{ Total } & 48 & & 48 & 100 \\
\hline
\end{tabular}

The data indicate that in general, the learners get benefits on the implementation of blended learning where only 9 or $19 \%$ of the learners at a low level. The indicator of success in the teaching and learning process at the Department of English Education where the present study was conducted is $80 \%$ of the learners graded between 71 and 100 .

We asked the following question to investigate the perception of the learners regarding the improvement in their grammar mastery: How do you perceive your grammar mastery after the implementation of blended learning? We classified the responses of the learners from the three different category levels to understand how each category perceive the improvement in their grammar mastery after the implementation of blended learning. The learners of the high category level perceive their grammar mastery is improved after the implementation of blended learning, first; the learners perceive that their grammar mastery and knowledge on grammar is improved due to the possibility to search for instructional materials from the internet during the application of blended learning as it is perceived by Q1, Q3, Q6, Q10, Q14, Q16, Q20, Q24, and Q25.

I think it gets improved because I can search and solve the material by my own, I get more knowledge; ... after using blended learning, there is a little bit improvement; My grammar knowledge is improved; ... my understanding in grammar through blended learning is a bit reasonable and I've started to understand even though just a little; I think my grammar is getting better.

Second, the learners perceive that their grammar mastery and knowledge on grammar is improved due to the possibility to have more time to train grammar usage by doing exercises at their own available time at home and elsewhere when they have access to study online as it is perceived by Q2, Q9, Q15, Q18, Q21, Q22, and Q23.

I think it is better because we are not only training our grammar in class but also at home. So we had a lot of time to train the exercises; I think I have more time to learn grammar everywhere when I have data to search the material; sometimes I can't master grammar when I learn in class but when I do my homework in Google Classroom I can learn by myself and add more knowledge; in blended learning, we have more practice at home and understand well about grammar.

The learners of the moderate category level perceive their grammar is improved due to the possibility to re-learn the instructional materials, to do the exercises, and to search instructional materials online as it is perceived by Q26, Q27, Q29, Q31, Q32, Q33, Q35, Q37, Q38, and Q39.

I think my grammar is better than before, even sometimes I forget the material but I can learn it again; very good because I learn Grammar in class also in an online class by finishing the assignment from the lecturer; my grammar increased because I have lots of time to search and learn more about grammar; my grammar is better than before, very good because I learn Grammar in class also in the online class.

Although most of the learners of the moderate category levels perceive improvement of their grammar mastery, there are four (4) learners, however, perceive their grammar mastery is not improved as much as they expect at the end of the class after the implementation of the blended learning as it is perceived by Q28, Q30, Q34, and Q36.

There are still many grammars to be fixed; for me, I still feel that my grammar mastery is still low; I need a lecturer to teach me more, it is hard to understand.

Different from the learners of the high and moderate category levels, some of the learners of the low category level perceive their grammar is improved and some are not. Interestingly, they do not describe any reason for their responses as the learners of the high and moderate category levels do. The learners who perceived that their grammar mastery is improved and increased after the implementation of blended learning are Q40, Q4, Q42, Q45, Q46, and Q4.

I think learning grammar through Blended Learning improves my grammar; my grammar is better than before. I get well improvement; it's getting better; I think it changed; it improves my grammar; I get more knowledge about grammar. 
The learners in the low category who perceive that their grammar mastery is not improved after the implementation of blended learning are $Q 43, Q 44$, and $Q 48$.

Not very good; My grammar is still very lack because I'm very slow in understanding grammar; I think it doesn't help me to improve my grammar. I just get a little bit of knowledge.

\section{B. Perception of the Learners on the Implementation of Blended Learning}

One of the perceptions needed from the learners in the teaching and learning process is related to teaching English Grammar by applying Blended Learning where they have to study the English Grammar online and offline to cope with the unexpected situation after the natural disaster experienced by the society in Central Sulawesi in general and Pasigala (Palu, Sigi, dan Donggala) regencies in Particular, where the English Department of the Faculty of Teacher Training and Education, University of Tadulako located. To investigate the learners' perception of teaching English Grammar, we proposed the following question: How did you perceive blended learning in learning Grammar?

The learners of the high category level perceive the use of blended learning in teaching grammar as; first, it is helpful, it helps them complete the grammar instructional materials that they have learned in the face to face classroom teaching when they are at home, and it allows them to spend more time to study at home, as it is perceived by Q1, Q2, Q6, and Q7.

It's very helpful because nowadays we're addicted to the internet. We can fill our spare time at home; we are not only learning in class but also have time to learn at home; in class, we learn about the material and we got online assignments at home.

Second, the learners perceive the use of blended learning in teaching grammar is easier since they got an explanation firstly in the face to face teaching in the classroom, as it perceived by Q3, Q5, Q16, and Q18.

I have a good experience because when it's face to face we got a clear explanation and when we have to do the task online it's going to be easier; honestly, learning grammar is good when in Blended Learning because it's easy to do.

Third, the learners perceive the use of blended learning in teaching grammar is flexible. The learners can do the grammar task based on their available time after the face to face teaching, as it is perceived by Q4, Q7, Q11, Q12, Q13, Q14, Q15, Q20, and Q24.

Blended learning is good especially online learning because it's flexible; I think it's good because I can choose the time, like when I can work or study at home; it is easy because when we send the assignment, we just send wherever and whenever we want.

Fourth, the learners perceive the use of blended learning in teaching grammar is fun. As a learner in the millennial era, that have been familiar with the internet or information and communication technology, it is considered that learning grammar through the application of blended learning is fun, as it is perceived by Q19.

I enjoyed learning grammar; I was interested in learning grammar although we know grammar is not easy to learn, it was fun I think for us as millennial to join in Blended Learning.

Finally, the learners of the high category level perceive that the teaching of grammar by applying blended learning allows them to have more time to learn and help them manage the use of the internet correctly. The learners have more chance to study grammar at their own, as it is perceived by Q8, Q22, and Q23.

Blended Learning is very useful because the learners can use the internet correctly; learning grammar through

Blended Learning was interesting and I think Blended Learning can add my learning time; Blended Learning is a good method because when we just use face to face the time is so limited. So to face a limited time, blended learning is a good way.

The learners of the moderate category level perceive blended learning as, first, it provides more study time. As the learners of the high category level, the learners of the moderate category level also perceive that the limited time in the face to face teaching is not sufficient to attain the instructional materials that have been taught so those instructional materials can be learned online at home and at a particular time available, as perceived by Q26, Q31, Q32, and Q37.

Not every learner in the class can understand the material so they can learn more the materials in the online class; learning grammar through blended learning can make me study more, I also must study at home; I think it's good because when I can't do the assignment in a certain time due to many works, I can finish it in another time; when we are in the online class, the assignment is given to us which indirectly makes us study more.

Second, the learners of the moderate category level also perceive that teaching grammar through blended learning make them get used to the internet-based or online learning, as perceived by Q27, Q28, Q29, Q30, and Q38.

Through Blended Learning I know how to apply the Google Classroom; many experiences that can be found and in the learning process we can know better on how to use the internet; I can use the internet for learning, and learn directly from the lecturer in class and do assignments then send it through online.

Finally, the learners of the moderate category level perceive that the implementation of blended learning in teaching grammar improves the ability to construct simple sentences and knowledge of grammar, as perceived by Q34 and Q35. I know how to construct sentences in simple past, present, and other tenses; the of knowledge that I first don't know and now I know. 
The learners of the low category level perceive that learning grammar through blended learning needs more experience and get an instant explanation. Unfortunately, one of the learners did not report any perception due to the inavailability of the mobile phone (Q46).

I still need more experience in learning grammar through Blended Learning; I think learning grammar through

Blended Learning can give us an instant explanation from the internet; I don't have a mobile phone.

Understandably, a learner from a low category does not have a cell-phone because of thousands of people during a natural disaster; the earthquake, tsunami, and liquefaction in Palu, Central Sulawesi in 2018, destroyed and eliminated the homes and property of thousands of people. Therefore, this learner's cell-phone could have been disappeared during the disaster.

\section{Obstacles on the Implementation of Blended Learning}

We posed the question as follows to investigate the obstacles or difficulties faced by the learners during the implementation of blended learning; what are the obstacles you faced in the teaching and learning process during the implementation of blended learning? The obstacles are related to; poor internet connection, slow feedback, and unclear instruction (reported by the learners of the high, moderate, and low category levels); electricity instability and getting nervous (moderate and low); difficult learning materials (low).

The obstacles faced by the learners of the high category level learners during the implementation of blended learning are a poor internet connection, slow feedback to the question in online teaching mode, and unclear instruction during online learning mode. The following is the response to the question during the interview.

In my home, I do not know why the XL network is really bad that is why sometimes I got trouble when I wanna finish my assignment; The difficulties, first is the network because we send assignments in Google Classroom so it needs a network. Secondly, for example, we work on a given assignment after we upload the assignment and want to ask for feedback is usually a slow response. We once had obstacles when given instructions on assignments, but we don't understand the instruction, so we immediately asked the lecturer via Google Classroom, but the slow response, so we did the assignments as much as we can. But actually, I prefer face to face learning because in my experience when I do not know about the material and then my lecturer gave me a task in Google Classroom when I gave him a question, I ask him like "would you mind to explain more about the task?" sometimes it is not interactive for us because he does not respond our question.

As has been reported by the learners of the high category level, the learners of the moderate category level also faced problems on poor network connectivity, the light is off and getting nervous. The following is the response to the question during the interview.

The obstacle is network connectivity. Because I only rely on Wi-Fi, when the light is off, it is enough to make me worried. But fortunately, the task deadline is a few hours from the time of giving so when the lights are on, then I do the assignments; It is on the internet connection. The internet connection is bad either at my home or on campus. In the classroom, face to face learning, the lecturer likes to point us randomly based on the attendant list to answer his question which makes us nervous.

Based on the learners of the low category, besides the aforementioned problems, the problem faced during the implementation of blended learning is the instructional materials are complicated. The followings are the responses to the question during the interview.

The problem is, usually, the instruction of assignment given in the online class is not clear so we confused what to do; before learning materials are given to the students, it is better to introduce it firstly; Learning material in articles is sometimes difficult to understand, it difficult to understand; it is better if we have friends so we can discuss the material because if I am alone, I need time to understand the material.

The learners of the three category levels also faced difficulties to access the internet at the campus, as we asked them the internet connectivity at the campus.

The media itself is really helpful because I can easily finish my assignment and do not need to write it down. For the connectivity, in my place is so bad that is why sometimes I get a problem while finishing the assignment; especially at the campus, the connectivity is very poor.

\section{DISCUSSION}

\section{A. Perceptions}

Blended Learning has been used in many language programs where face to face teaching and learning processes are combined with ICT in online learning mode. Many online platforms have been applied in teaching English and it is proved that they are easily accessed to support the face to face teaching-learning process (Baturay et al., 2010). The implementation of blended learning has been used to cope with many learning situations and conditions nowadays and it is proved that the integration of ICT is effective and motivating (Campbell et al., 2008). Considering the effectiveness of blended learning particularly in improving language mastery and motivation, the present study investigates perceptions of EFL learners at the English Department at the Faculty of Teacher Training and Education, Tadulako University. The study is also in line with the idea of arguing that in limited class time setting the implementation of 
blended learning is a solution (Banados, 2006; Sahin-Kizil (2014). The limited-time in the teaching at Tadulako University was also experienced due to the natural disaster where available classrooms for the teaching-learning process were limited. Therefore the present study attempts to investigate the perceptions and the difficulties of the learners after experiencing blended learning mode.

After the implementation of blended learning in teaching and learning grammar it is perceived that not all learners get used to online learning. Some learners benefit from the involvement of ICT and some of them are not even familiar with online learning. Those who have been familiar with the ICT in online learning mode get a benefit, and it can be seen from the analysis of the document where $52 \%$ of learners are in the high category and $29 \%$ in the moderate category in the grammar class. There is only $19 \%$ in the low category and they reported that they have not got enough experience in the use of online learning, they expect that the online learning gives them an instant explanation, they do not consider blended learning as a good learning mode, and even one low category learners reported that no cellular phone is available at hand. While the high and middle category learners report that learning grammar through blended learning is helpful and allows them to learn at home, they perceive that the use of online learning provides them with more study time. It is also said that online learning as part of blended learning is a technique for them to fill in their spare time, and more importantly, the technique is fun, flexible, and easy for them to use. This implies that not all of the learners have been familiar with blended learning, particularly in the online learning part. Therefore, it is important to note that before the implementation of the online learning part in blended learning, there must be data of the learners who have been familiar with the online learning part and who have not. For those who have not been familiar with online learning, there must be specific treatment. This has also been argued by Selwyn (2016) that more guidance and training are needed to satisfy the needs of learners in the use of ICT at a low-level. However, in general, the learners perceived blended learning as beneficial in their grammar class and it can be used to cope with the limited time available in the teaching of grammar. This is in line with the previous researchers arguing that the implementation of blended learning is beneficial for language learners (Lin, 1997; Ellis, 2003; Byrne, 2007; Tuson, 2015).

Many language programs have implemented blended learning to improve language mastery. It is reported that the implementation of blended learning improves language skills (Abdelhak, 2015). The present study also reveals that blended learning motivates learners to learn grammar. The learners perceived that their grammar mastery is improved after studying using blended learning because they can look for materials on the internet themselves, they have more time to train the use of grammar during online learning particularly while doing exercises, and more importantly, the learners get actively involved. This implies that the grammar can be learned autonomously if the learners can use effectively the online learning part of blended learning. In other words, the implementation of blended learning does not only improve the grammar mastery but it also builds up and train the learners to be independent learners. This is in line with the previous study indicating that teaching grammar using ICT was helpful to enhance individualized learning (Lin, 1997). Therefore, it is important to implement blended learning in this era as suggested in the industrial revolution Era 4.0, because more and more learners are addicted to the advances in ICT, that they spend the ICT to support their learning process independently. More importantly, the learning becomes more contextual.

In general, the learners perceived that the implementation of blended learning is effective. The blended learning model is useful to improve their grammar knowledge, to improve their study time particularly out of class activities, and to get familiar with ICTs in language learning. More importantly, the implementation of blended learning builds up the motivation to conduct independent learning.

\section{B. Obstacles.}

The involvement of ICTs in teaching and learning process has been seen as the complement to the face to face teaching. The advancement of ICTs has been experienced widely particularly in the introduction of the Industrial Revolution Era 4.0 in almost all human life and language teaching has no exception. Some researchers have reported the positive influence of the ICTs in the online learning mode (Abuseileek, 2009; Baturay et al., 2010). More importantly, it is argued that blended learning does not only beneficial for the learners but also the teaching staffs especially in classroom management (The University of Western Sydney, 2013). Concerning these findings, the present study investigates the obstacles faced by the learners in the implementation of blended learning.

The learners perceive the implementation of blended learning as beneficial as has been described in the previous section, but they also face difficulties in learning grammar during its implementation. The obstacles are mostly related to; poor internet connection, slow feedback, and unclear instruction (reported by the learners of the high, moderate, low category levels); electricity instability and getting nervous (moderate and low); difficult learning materials (low).

The first obstacle as the main problem is related to internet connectivity. The learners perceive during the implementation of online learning in the blended learning model, the internet connection is poor. It takes too long for them to access and to send their response online. They often cannot satisfy the due time in the submission of the assignment. It implies that before the implementation of blended learning, it is useful to ensure that internet connectivity is provided particularly at the campus. The problems on internet connectivity have also been reported in research at rural schools in Indonesia when the pre-service EFL teachers when they did their teaching practice (Maudra, 2018).

The second obstacle is slow feedback or late response of the lecturer on online learning. It is important to note that during the online learning mode the instructor should be consistently online so that questions from the learners can be followed up as soon as possible. The next obstacle is unclear instruction. The learners perceived that the instruction 
during online learning is difficult to understand and if it happens it is difficult to get a direct response on the explanation from the lecturer. The two obstacles are related to the conduct of online learning from the lecturer's part. Therefore, the lecturer has to consistently implement good classroom management as it is argued by the Blended Learning team at The University of Western Sydney (2013).

The following obstacle is related to electricity instability. The electricity is too often cut-off or blackout during the implementation of blended learning so at the same time the internet connection is also off. Consequently, the online learning model as part of blended learning is discontinued. It implies that the electricity should be provided at campus should blended learning is assigned. The electricity is highly related to the internet connection. The final obstacle is related to complex or difficult instruction and instructional materials that are faced by the learners of the low level. In the implementation of blended learning, it is better if the materials are designed based on the needs and the situation (Richards, 2001; Manurung, 2017). It implies that the language used is simple and the contents are contextual.

\section{IMPLICATION}

No doubt the implementation of blended learning is beneficial and contributed to coping with problems faced by institutions in an abnormal learning system. Based on the findings of the present study, it is recommended that; first, before implementing the online part of the blended learning it is important to introduce to the learners the procedure of the utilization of the chosen online platform and would be better if short training or socialization is conducted to all of the learners, particularly if there are learners who have not been familiar with the online learning system, or in using the internet. Second, the institution needs to provide a stable internet connection and electricity. In the condition as in Palu, most learners are heavily dependent on the use of internet connection at the campus. Third, there must be instructional materials purposively designed to meet the requirement of the online learning model, for example, the materials which are written in simple language so that they easily understood, particularly about the instruction. It is better to use both English and Bahasa Indonesia, the native language of the learner.

\section{ACKNOWLEDGMENTS}

We would like to thank the learners enrolled in Grammar Course in the 2018/2019 academic year at the Department of English Education, Faculty of Teacher Training and Education, University of Tadulako, Palu, Indonesia, who have actively participated in this study.

\section{REFERENCES}

[1] Abdelhak, E. (2015). An ICT-based approach to teaching civilization to EFL learning. Arab World English Journal, 6(1), 185-199.

[2] Abuseileek, A. F. (2009). The effect of using an online-based course on the learning of grammar inductively and deductively. ReCALL: The Journal of EUROCALL, 21(3), 319-336.

[3] Al-Jarf, R. (2005). The effects of on-line grammar instruction on low proficiency EFL college students' achievement. The Asian EFL Journal Quarterly, 7(4), 166-190.

[4] Allen, M., Bourhis, J., Burrell, N., \& Mabry, E. (2002). Comparing student satisfaction with distance education to traditional classrooms in higher education: A meta-analysis. American Journal of Distance Education, 16(2), 83-97.

[5] Ayres, R. (2002). Learner attitudes towards the use of CALL. Computer Assisted Language Learning, 15(3), 241-249.

[6] Banados, E. (2006). A Blended Learning Pedagogical Model for Teaching and Learning EFL Successfully Through an Online Interactive Multimedia Environment. CALICO Journal, 23(3), 533-550.

[7] Basioudis, I. G., De Lange, P. Suwardy, T., \& Wells, P. (2012). Accounting students' perceptions of a learning management system: An international comparison. Accounting Research Journal, 25(2), 72-86.

[8] Baturay, M. H., Daloglu, A., \& Yildirim, S. (2010). Language practice with multimedia supported web-based grammar revision material. ReCALL: The Journal of EUROCALL, 22(3), 313-331.

[9] Bonk, C. \& Graham, C. (2006). Handbook of Blended Learning. USA: Jossey-Bass Inc.

[10] Bueno-Alastuey, M. C., \& López-Pérez, M. V. (2014). Evaluation of a blended learning language course: students' perceptions of appropriateness for the development of skills and language areas. Computer Assisted Language Learning, 27(6), 509-527.

[11] Byrne, T. (2007). Marrying two existing software packages into an efficient online tutoring tool. Computer Assisted Language Learning, 20(5), 459-468.

[12] Campbell, A., Brown, I., \& Weatherford, Y. (2008). A CALL Project with Low-Level EFL Students. The 3rd World CALL International Conference. Fukuoka, Japan.

[13] Creswell, J. W. (2014). Research Design: Qualitative, Quantitative, and Mixed Methods Approaches. California: SAGE Publication, Inc.

[14] Department of Education and Early Childhood Development. (2012). Blended learning: A synthesis of research findings in Victorian education 2006-2011. Victoria: Ultranet and Digital Learning Branch.

[15] Driscoll, M. (2002). Blended Learning: Let's get beyond the hype. E-Learning, 1(4), 1-3.

[16] Dziuban, C. D., Hartman, J., \& Moskal, P. (2004). Blended Learning. Educause Center for Applied Research Bulletin, 7, 1-12.

[17] Ellis, R. (2003). Grammar Teaching-Practice or Conscious Raising? In: J. C. Richards, J. C \& W.A. Renandya (Eds.), Methodology in Language Teaching: An Anthology of Current Practice (pp. 167-174). Cambridge: Cambridge University Press. 
[18] Flórez, E. G., Pineda, J. E., \& García, N. M. (2012). EFL Students' Perceptions about a Web-Based English Reading Comprehension Course. Profile, 14(2), 113-129.

[19] Ginns, P. \& Ellis, R. (2007). Quality in blended learning: Exploring the relationships between on-line and face-to-face teaching and learning. Internet and Higher Education, 10, 53-64.

[20] Lambert, V. A. (2012). Contrastive analysis and error analysis ( $2^{\text {nd }}$ ed.). Tehran, Iran: Rahamana Press.

[21] Lee, K. C., \& Chong, P. M. (2007). An observational study on blended learning for Japanese language studies. In Fong, J., \& Wang, F. L. (Eds.), Blended learning (88-100). Edinburgh, Scotland: Pearson.

[22] Lin, C. H. M. (1997).Teacher's Tips: Online Grammar Teaching and Learning. Society for Reading and Literacy (Singapore) News magazine, 9 (3), 11-12.

[23] Manurung, K. (2005). Instructing language learning strategies to promote autonomous learning. Indonesian JELT, 1(2), 66-90.

[24] Manurung, K. (2015). Improving the speaking skill using reading contextual internet-based instructional materials in an EFL class in Indonesia. Procedia-Social and Behavioral Sciences, 176, 44-51.

[25] Manurung, K. (2017). Designing Instructional Materials. Palu: Untad Press.

[26] Manurung, K. (2018). In search of an Instructional Material Design Model to Support the Implementation of IQF Oriented Curriculum at HEIs. Advances in Social Science, Education and Humanities Research, volume 174, 202-206.

[27] Manurung, K., Kamaruddin, A., \& Mertosono, R. S. (2019). Peningkatan kemampuan Grammar dalam penerapan Kurikulum berorientasi KKNI berbasis Blended Learning. Lembaga Penelitian dan Pengabdian Kepada Masyarakat Universitas Tadulako. Unpublished Research Report.

[28] Maxwell, J. (1997). Designing a qualitative study. In L. Bickman \& D. J. Rog (Eds.), Handbook of applied social research methods (pp. 69-100). Thousand Oaks: Sage.

[29] Mudra, H. (2018). Pre-Service EFL Teachers' Experiences in Teaching Practicum in Rural Schools in Indonesia. The Qualitative Report, 23(2), 319-344.

[30] Nazara, S., \& Wardaningsih, E. F. F. (2016). Students' Attitude towards Face-to-Face and Blended Learning Instruction in English Class. A paper presented at UKI English Education Department Collegiate Forum.

[31] Neuendorf, K. A. (2002). The content analysis guidebook. Thousand Oaks: Sage.

[32] Neumeier, P. (2005). A closer look at blended learning: Parameters for designing a blended learning environment for language teaching and learning. ReCALL, 17(2), 163-178.

[33] Pardede, P. (2011). Using BALL to develop writing skills: students' interest and perception. Paper presented at SWCU International Conference Satya Wacana Christian University, Salatiga.

[34] Pierce, C. (1995). A Model for self-access language provision. Language learning journal, 11, 30-32.

[35] Pollard, A. (2015). Web-based journals in the classroom: Motivation and autonomous learning. Indonesian Journal of Applied Linguistics, 4(2), 20-31.

[36] Richards, J. C. (2001). Curriculum Development in Language Teaching. New York: Cambridge University Press.

[37] Sahin-Kizil, A. (2014). Blended instruction for EFL learners: Engagement, learning, and course satisfaction. Jaltcall journal, 10(3), 175-188.

[38] Seliger, H., W., \& Shahomy, E. (1990). Second language research methods. Oxford: Oxford University Press.

[39] Selwyn, N. (2016). Digital downsides: exploring university students' negative engagements with digital technology. Teaching in Higher Education, 21(8), 1006-1021.

[40] Sheerin, S. (1989). Self-Access: Resource books for teachers. Oxford: Oxford University Press.

[41] Singh, Y. K. (2006). Fundamental of Research Methodology and Statistics. New Delhi: New Age International (P) Limited.

[42] Sugiono. (2012). Metode Penelitian Pendidikan: Pendekatan Kuantitatif, Kualitatif, dan R\&D. Bandung: Alfabeta.

[43] The University of Western Sydney. (2013). Fundamentals of Blended Learning. Sydney: Blended Learning Team, Learning, and Teaching Unit UWS.

[44] Tuson, S. (2015). The effects of blended learning on EFL students' vocabulary Enhancement. GlobELT: An International Conference on Teaching and Learning English as an Additional Language, Antalya- Turkey. Procedia - Social and Behavioral Sciences, 199, $641-647$.

[45] Yang, S. C. \& Chen, Y. J. (2007). Technology-enhanced language learning: A case study. Computers in Human Behavior, 23, 860-879.

[46] Yarbro, J., McKnight, K., Elliott, S., Kurz, A., \& Wardlow, L. (2016). Digital Instructional Strategies and Their Role in Classroom Learning. Journal of Research on Technology in Education, 48(4), 274-289.

Grace N. Manurung was born in Palu on 25 November 1996. She earned her S.Pd in English Education in 2018 at the Department of English Education, Faculty of Teacher Training and Education, Tadulako University Palu. She joined SEAMEO SEA Teacher Program Batch IV in Roosevelt College Inc., Cainta, Rizal, Philippines in 2017. She is a student researcher at the Department of English Education, Postgraduate Program, Tadulako University, Palu, Indonesia.

Konder Manurung was born in Lumban Manurung on 19 August 1965. He earned his Doctorate Degree in Education in 2002 at the School of Education, La Trobe University, Australia. He is a lecturer at the Department of English Education, Faculty of Teacher Training and Education, University of Tadulako, Palu, Indonesia. His research interest includes TEFL Methodology, Curriculum and Instructional Design, and Self-Access Materials Development.

Sudarkam R. Mertosono was born in Lopito, Banggai Kepulauan on 23 July 1968. He did his Doctorate Degree in the Faculty of Human and Social Sciences, School of Humanities, Asian Studies Program focusing on Local Content Curriculum and Teacher and 
Certification, La Trobe University, Australia. He is a lecturer at the Department of English Education, University of Tadulako, Palu, Indonesia. His research interest includes Issues on Vocabulary Development, Local Content Curriculum, Teacher Certification, and Language Skills.

Abdul Kamaruddin was born in Bolokut on 28 September 1974. He completed his Ph. D in Education in 2015 at the School of Education, La Trobe University, Australia. He is a permanent lecturer at the Department of English Education, Faculty of Teacher Training and Education, University of Tadulako, Palu Indonesia. He is interested in conducting research in the area of TEFL Methodology, English Language Teaching Assessment, and Curriculum and Instructional design. 